\section{Re: Faglige svar og etiske spørsmål ved ikke-invasive prenatale tester}

Bjørn Hofmann har fått mye spalteplass i Tidsskriftet i det siste $(1-4)$. Alle innleggene har hatt samme budskap: Det er på tide å diskutere de etiske sidene av non-invasiv prenatal testing (NIPT). Jeg er ikke i tvil om at en professor i medisinsk etikk har mye å lære norske leger om vanskelige etiske spørsmål, men beskrivelsene av NIPT og testens egenskaper bærer preg av at dette ikke er Hofmanns fagfelt (1-4).

I Tidsskriftet nr 102014 (4) skriver Hofmann om resultatene fra en ny amerikansk studie (5). Studiens hovedbudskap er ifølge etikkprofessoren at «over halvparten av de positive testene er falskt positive» (4). Førsteforfatteren, professor Diana Bianchi, la frem resultatene fra den amerikanske studien på en nordisk kongress i fødselshjelp og kvinnesykdommer i Stockholm 12.05.14. Etter å ha hørt henne forelese, er det vanskelig å forstå at Bjørn Hoffmann kan ha lest og forstått artikkelen hennes.

I Hofmanns fremstilling kommer det ikke tydelig frem at det som skiller denne studien fra de fleste andre, er at den er gjort $i$ en befolkning med lav risiko for at fosteret har trisomi. Alle leger lærer på medisinstudiet at positiv (PPV) og negativ prediktiv verdi (NPV) avhenger av sykdommens prevalens, og dette er dermed en vesentlig opplysning.

En metaanalyse av alle publiserte studier per desember 2013 viste at NIPT kan diagnostisere trisomi 21 (Downs syndrom) med sensitivitet $99,0 \%$ og falsk positiv rate $0,08 \%(6)$. Den amerikanske studien Hofmann omtaler, hadde vesentlig høyere falsk positiv rate (fire falske positive av 1365 prøver, dvs. 0,3\%) (5). I Norge tilbys prenatal diagnostikk hovedsakelig til kvinner over 38 år med aldersrisiko for trisomi 21 på ca. $1 \%$. Om vi appliserer tallene fra metaanalysen til norske forhold, får vi PPV $93 \%$ og NPV 99,99\%. Om vi bruker tallene fra den amerikanske studien på en norsk populasjon av kvinner over 38 år, finner vi PPV $77 \%$ og NPV 99,99\%.

Ved senere omtaler av nye studier om NIPT, vil jeg be om at resultatene overføres til norske forhold og gir leseren nødvendig informasjon.

Kjell Å. Salvesen

pepes@ntnu.no

Kjell Å. Salvesen (f. 1958) er professor ved Lunds Universitet og ved NTNU.

Ingen oppgitte interessekonflikter.

\section{Litteratur}

1. Hofmann B. Forbedret fosterdiagnostikk? Tidsskr Nor Legeforen 2013; 133: 2336.

2. Hofmann B. B. Hofmann svarer. Tidsskr Nor Legeforen 2014; 134: 265-6.

3. Hofmann B. Re: Fosterdiagnostikk med blodprøver. Tidsskr Nor Legeforen 2014: 134: 692.

4. Hofmann B. Faglige svar og etiske spørsmål ved ikke-invasive prenatale tester. Tidsskr Nor Legeforen 2014; 134: 1028.

5. Bianchi DW, Parker RL, Wentworth J et al; CARE Study Group. DNA sequencing versus standard prenatal aneuploidy screening. N Engl J Med 2014; 370 799-808.

6. Gil MM, Akolekar R, Quezada MS et al. Analysis of cell-free DNA in maternal blood in screening for aneuploidies: Meta-analysis. Fetal Diagn Ther 2014; PMID: 24513694

\section{Re: Faglige svar og etiske spørsmål ved ikke-invasive prenatale tester}

I min kommentarartikkel i Tidsskriftet (1) viser jeg til nyere studier som begynner å gi oss svar på de faglige spørsmålene som ikkeinvasive prenatale tester (NIPT) reiser. Samtidig reiser jeg konkrete etiske spørsmål til dem som har argumentert heftigst for innføring av NIPT i Norge (2-3). Jeg har tidligere stilt Salvesen følgende spørsmål: «Hva er det med Downs syndrom spesielt, som gjør at det er verdt å bruke minst 390.000,-- norske kroner på hvert ekstra tilfelle som oppdages? Og hvorfor skulle vi ikke samtidig kunne undersøke en lang rekke andre tilstander?» (4). Salvesen har så langt ikke gitt meg svar på dette.

Siden Salvesen argumenterer så ivrig for å innføre NIPT (3), ber jeg ham eksplisitt om å svare på følgende spørsmål: Hvilke kriterier skal vi bruke for å kunne lete etter og fjerne fostre med bestemte tilstander? Hva er det ved tilstandene som kvalifiserer til fravalg? Bruk gjerne Downs syndrom som eksempel, men tenk også gjennom de andre mulighetene for testing som vil komme. Salvesen har i store deler av sitt yrkesaktive liv arbeidet med å påvise fostre med trisomi $21 \mathrm{og}$ ivret for å forbedre metodene for dette, så han burde være godt kvalifisert til å svare på spørsmålet.

Når jeg har fått svar på dette og andre viktige spørsmål som NIPT reiser $(1,6)$, er jeg mer enn gjerne med på å diskutere hvordan testnøyaktigheten blir for den norske befolkningen. Salvesen og kollegaer har vist at aldersgrensen på 38 år ikke følges av et flertall av legene (5), slik at risikoen i den gruppen som undersøkes i dag, er lavere enn hva Salvesen oppgir i sin kommentar.

Jeg ser frem til at Salvesen svarer på det han blir spurt om.

\section{Bjørn Hofmann}

b.m.hofmann@medisin.uio.no

Bjørn Hofmann (f. 1964) er professor på Høgskolen i Gjøvik og Universitetet i Oslo.

Oppgitte interessekonflikter: Hofmann har vært med på å utrede de etiske aspektene ved ultralyd i Kunnskapssenterets rapporter (2008, 2012). Han har også vært medlem av Sosial-og helsedirektoratets referansegruppe for biofaglige spørsmål (Bioreferansegruppa, 2007-2010). Han er spesielt interessert i verdispill i forbindelse med innføring av ny bioteknologi, og særlig opptatt av skjulte og nedtonede verdier. Åpenhet og transparens er sentrale prinsipper for hans perspektiv i etiske spørsmål.

\section{Litteratur}

1. Hofmann B. Faglige svar og etiske spørsmål ved ikke-invasive prenatale tester. Tidsskr Nor Legeforen 2014; 134: 1028

2. Hov GG, Åsberg A, Thorstensen K. Misvisende om fosterdiagnostikk. Tidsskr Nor Legeforen 2014: 134: 264-5.

3. Salvesen KÅ. Fosterdiagnostikk med blodprøver. Tidsskr Nor Legeforen 2014; 134: $388-9$.

4. Hofmann B. Flere tester for det samme, og mer til? Tidsskr Nor Legeforen 2014; 134: 692.

5. Røe K, Salvesen KÅ, Eggebø TM. Blir retningslinjene for fosterdiagnostisk ultralyd fulgt? Tidsskr Nor Legeforen 2012; 132: 1603-6.

6. Hofmann B. Etiske utfordringer med non-invasive prenatale tester (NIPT). Etikk i praksis 2014; 8(1): 67-87. 